\title{
UN OFICIO ADQUIRIDO
}

\section{Leila Guerriero}

Iba a escribir «la idea no se me hubiera ocurrido nunca» pero es mentira: yo huía de la idea como de la peste. Soy periodista desde 1991 o 1992, y por entonces estaba segura de que, en caso de que alguno de los medios donde trabajaba decidiera nombrarme editora, yo presentaría mi renuncia. Tenía claro que ese «ascenso» era un regalo envenenado: la fórmula perfecta para dejar de escribir. Yo quería lidiar con mis propios textos, no con textos ajenos. Editar era una tarea a la que no le veía ninguna gracia y que, según yo, consistía en pasarse horas mejorando, reescribiendo o corrigiendo lo que escribían (mal) los demás. De modo que esquivé esa posibilidad hasta que un día de 2006 Guillermo Osorno, director de Gatopardo, una publicación mexicana dedicada al periodismo narrativo donde yo escribía desde hacía tiempo, me propuso ser editora de esa revista para latinoamérica. Podría hacerlo desde Buenos Aires, trabajaría con artículos de periodistas a los que conocía y admiraba y, sobre todo, me permitiría seguir escribiendo. Aunque yo no sabía nada de edición, Guillermo hizo lo que hace un buen editor: me empujó hacia mi propia incertidumbre diciendo «Puedes hacerlo, porque lo haces todo el tiempo: tú te editas a ti misma». Desde entonces, allí estoy. En el año 2009, Matías Rivas, director de Ediciones Universidad Diego Portales, de Chile, fue el primero en proponerme editar libros cuando me ofreció armar, desde cero, un volumen de perfiles sobre escritores malditos latinoamericanos. Mi tarea consistía en elaborar una lista de «malditos», seleccionar autores para que escribieran los perfiles, y editarlos. El libro se publicó en 2011 y, desde entonces, allí estoy. Ahora sigo siendo alguien que sobre todo escribe, pero ya no imagino mi vida sin ese oficio -el de editora de no 
ficción- que adquirí gracias a que otros me empujaron a él. Claro que, al principio, no sabía cómo hacerlo ¿Qué era editar: corregir, mejorar, reescribir? No era, por supuesto, nada de todo eso. Era algo mucho más parecido a lo que había hecho alguna vez Homero Alsina Thevenet, mi editor uruguayo, llamándome por teléfono desde Montevideo a Buenos Aires para decirme: «Muchacha, tu nota está buenísima pero se ve que en el final te cansaste ¿Por qué no buscás otro final que esté a la altura del resto?»; era algo mucho más parecido a la carcajada con la que el periodista y escritor argentino Elvio Gandolfo me había dicho una mañana en un bar de Palermo: «Tu nota está fenomenal, ipero si te piden 10 mil caracteres escribí 10 mil, no el doble! Al cortar la mitad, la estructura cambia por completo»; era algo mucho más parecido a la delicada astucia con que Rodrigo Fresán me había sugerido que reescribiera una nota dándole una estructura más cinematográfica, arrojándome, con esa sugerencia, a un infinito de posibilidades narrativas. Editar no era corregir ni mejorar ni reescribir, sino alentar y guiar con gracia a alguien en la búsqueda del mejor texto posible. Yo tenía, en verdad, cierta ventaja: vivía a ambos lados del espejo. Era editora pero, a la vez, me editaban. Sabía que cuando un autor entrega un trabajo espera una respuesta con ansiedad porque yo misma, cuando entrego un trabajo, espero una respuesta con ansiedad, así que, como editora, procuré responder tan rápido como me fue posible; sabía que los autores están mejor dispuestos a trabajar en un texto si su editor sugiere y argumenta con delicadeza porque yo misma tiendo a no respetar a los editores que confunden inteligencia con cinismo o erudición con maltrato, así que, como editora, procuré mantenerme alejada de los comentarios irónicos, no llevar nunca la conversación a un plano personal, y no transformar la edición en una puja por ver quién leyó más libros; sabía que no hay nada más desconcertante para un autor que un editor que no sabe lo que quiere porque yo misma padecí editores balbuceantes que un día querían un enfoque, al día siguiente otro y al próximo los dos juntos, así que, como editora, intenté ser clara y reducir los planteos a unas pocas líneas precisas; sabía que un autor espera que se respete su propia voz porque yo misma lo espero, así que, como editora, procuré escindirme y no editar un texto como si yo lo hubiera escrito. Entendí muy pronto que un editor es un zelig que adapta su forma de trabajo -no su rigurosidad ni sus criterios- a cada autor: hay, por ejemplo, quienes necesitan compartir cada paso de su reporteo, y hay quienes no sueltan nada antes de terminar, de modo que yo no exijo información si no me la dan pero, si me la dan, opino tanto como me lo permiten. Y, sobre todo, entendí que un editor 
establece dos relaciones, una con el texto y otra con el autor, y que de su habilidad depende hacerlas confluir para traer al mundo la mejor versión posible de una obra.

De todos los cuestionamientos que le hago a un artículo o a un libro, empiezo siempre por el mismo: ¿tiene algo para decir y lo dice de la mejor manera posible? Sigue, a eso, una lista infinita: ¿la estructura es confusa, artificiosa, se ajusta a lo que se quiere contar; hay reiteraciones, lugares comunes, exceso de estilo? Como se trata de textos de no ficción, tengo en cuenta aspectos específicos: ¿hay datos de contexto (no es lo mismo el año 1976 en España que en Panamá que en la Argentina); se incluyen todas las fuentes -las voces de las víctimas y de los victimarios, de los denunciados y de los denunciantes-; están facetados los personajes o hay buenos excesivamente buenos y malos excesivamente malos; se sostiene la verosimilitud (en ocasiones, la realidad se empeña en ser inverosímil); se entienden los motivos de los actos de las personas involucradas o son títeres que se mueven sin sentido? Finalmente, envío un correo con mis comentarios y sé que de ese correo depende que el autor se sienta bien dispuesto a trabajar en el error de paralaje que a veces existe entre lo que el texto es y lo que podría ser, o que todo termine amargamente. Y también sé que, si hice mi tarea como corresponde, nadie sabrá que estuve allí.

En Egos revueltos (Tusquets, 2010) Juan Cruz Ruiz recordaba que en 1996, cuando dirigía Alfaguara, llegó a su casa y en Navidad y encontró dos Ilamadas en el contestador: «Un autor se había sentido decepcionado porque en la librería de unos grandes almacenes no estaba su libro y otro me reprochaba que no hubiera recibido una invitación para ir a una copa navideña de la editorial (...) Navidad, soledad absoluta, el editor regresa a casa y ese es el bagaje que le ha dejado la despedida del año (...) La asignatura más difícil de los editores es el aprendizaje del respeto del ego (...) El editor asume que ha de estar en segundo plano (...) cuenta las buenas nuevas de sus autores, él no existe (...) En el mundo editorial te pagan para que seas opaco, una sombra detrás de la luz de los autores». La editora chilena Andrea Palet, en su Brevísimo manual para jóvenes editores, lo escribió así: «Sé una digna sombra. La cualidad número uno del editor respetable es la capacidad de quedarse inmensamente callado. Responsabilidad, tacto, oído y un punto de vista personal son indispensables también, pero, precisamente porque cuesta mucho, saber quedarse callado tiene un punto de decencia o nobleza añadido, si es que le atribuimos nobleza a la dificultad. Es duro ser una sombra, y ni siquiera eso te lo van a agradecer, pero si 
eres editor es porque te gustan los libros, leerlos, tocarlos, rodearte de ellos, pensarlos, crearlos: bien, ésa y no otra ha de ser tu callada recompensa». No sé si aprendí a editar. Pero aprendí que la edición implica tres movimientos: entrega, generosidad y desaparición.

Tiempo atrás edité un libro que recopila el trabajo del escritor argentino Martín Kohan: columnas, ensayos, conferencias. Estuve mucho tiempo leyendo el material disperso, buscando un hilo conductor, disponiendo los textos de manera que se potenciaran entre sí, que brotara del conjunto una atmósfera determinada. El libro, Fuga de materiales, se publicó en 2013 en la UDP. Después de la publicación, Martín Kohan me envió un correo diciendo que quería verme. Nos encontramos en un bar. El siempre escribe a mano en cuadernos de marca Rivadavia. Cada uno es un original irrepetible, con las enmiendas, tachaduras y anotaciones de todo trabajo en proceso. Aquella tarde conversamos un rato. Antes de despedirnos me dijo: «Tengo algo para vos». Abrió su mochila negra y sacó un cuaderno de tapas verdes en el que había escrito, años antes, algunos de los textos incluidos en Fuga de materiales. Ese cuaderno, que tengo en mi biblioteca, me recuerda en qué consiste el oficio de editar: en recibir el más valioso tesoro de un autor -su escritura en estado puro- y guardarlo en secreto. 